\title{
308 円柱体に衝突する超音速噴流の自励振動に及ぼす圧力比と位置の影響
}

\author{
Influence of Pressure ratio and Position on Self Induced Flow Oscillation \\ Caused by Supersonic Jet Impinging Cylindrical Body
}

○ 佐々木 雄一 (北九州高専 専攻科) 正 安信 強 (北九州高専)
正 田上 宗男 (北九州高専)

Yuichi SASAKI, Hideo KASHIMURA, Tsuyoshi YASUNOBU and Muneo TAGAMI

Kitakyushu College of Technology, 5-20-1 Sii, Kokuraminami-ku, Kitakyushu, 803-0985, JAPAN

Keywords:Flow Oscillation, Supersonic jet, Mach Disk, Compressible Flow

\section{1. はじめに}

超音速噴流が物体に衝突するとき，噴流中のマッハディス クが流れ方向に自励振動する場合があることが知られてい る ${ }^{(1)}$.このような振動現象は, 例えば高圧ガスバルブ中で騒 音を引き起こす原因 ${ }^{(2)}$ ともなっており, 自励振動の発生機構 や特性などを解明する必要があるが, まだ充分な検討がなさ れているとは言えない, 一本研究では, 超音速噴流が円柱体に 衝突する場合の自励振動に及ぼす圧力比および, 円柱体の位 㯰の影響について実験的に考察する.

\section{2. 実験装置および実験方法}

本研究で用いた実験装置の系統図を Fig.1 に示す．本実験 装置は, 高圧室, 真空室および測定部から構成されており, 测 定部に出口直径 $\mathrm{D}=4 \mathrm{~mm}$ の音速ノズルと, ノズル出口から $\mathrm{x}_{\mathrm{c}}=8,12,16,20 \mathrm{~mm}$ の位置に直径 $\mathrm{d}_{\mathrm{c}}=12 \mathrm{~mm}$ の円柱体を設置した. 本研究では, 貯気圧 $\mathrm{p}_{0}$ 之背圧 $\mathrm{p}_{\mathrm{b}}$ との圧力比 $\phi\left(=\mathrm{p}_{0} / \mathrm{p}_{\mathrm{b}}\right)$ を 4 $\leqq \phi \leqq 19$ の範囲で変化させて超音速噴流を発生させ, 円柱体 、に衝突させて自励振動を生じさせた. 円柱体表面には圧力セ ンサ（Kulite 社製, XTM-190-100G）が設置されており，セン サからの出力電圧は直流增幅器 (TEAC 社製, SA-57) で増幅さ れたのち, ディジタルストレージスコープ (IWATSU 社 製, DS-8608）に記録され, さらにパーソナルコンピュータに 転送して保存される.このデータを FFT プログラムで解析し て,圧力変動の周波数成分を調べ，さらに数值積分により， 時間平均圧力を求めた.

超音速噴流が円柱体に衝突するときの流れのモデルを Fig. 2 に示す. 流れ場内にはバレル衝撃波やマッハディスク が形成され，マッハディスクが流れ方向に自励振動する、マ ッハディスクの形成位置によって, 図に示すように円柱体前 面に圧力じょう乱が形成され，円柱体前面の圧力は上昇する.
本研究ではノズル出口直径 D により無次元化を行なった.

\section{3. 実検結果と考察}

本実験で得られた円柱体表面中心の圧力波形の一例を Fig. 3 に示す.このときの円柱体の無次元位置は $\mathrm{xc} / \mathrm{D}=3$, 圧力比 は $\phi=10$ である. 図より, $\mathrm{t}=2.5 \mathrm{~ms}$ で振幅が急激に増加し， 自励振動が発生していることがわかる，また，自励振動時の 振幅は時間の経過とともにほぼ一定になる傾向を示す. 本研 究では, 振幅の変動が小さくなった領域で解析を行なった.

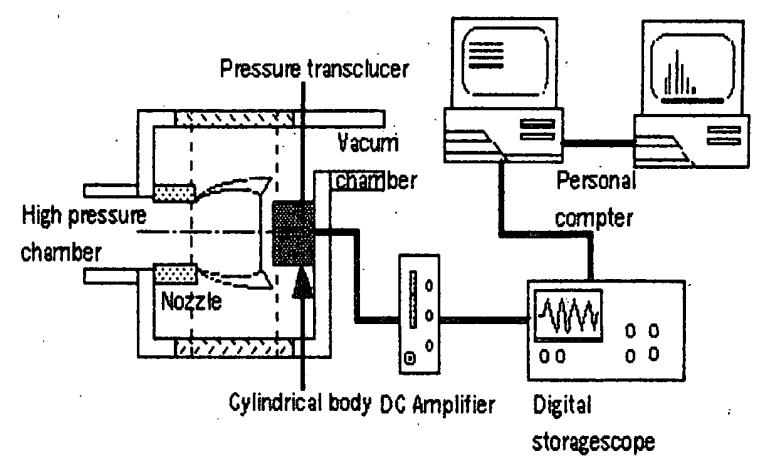

Fig. 1 Experimental apparatus

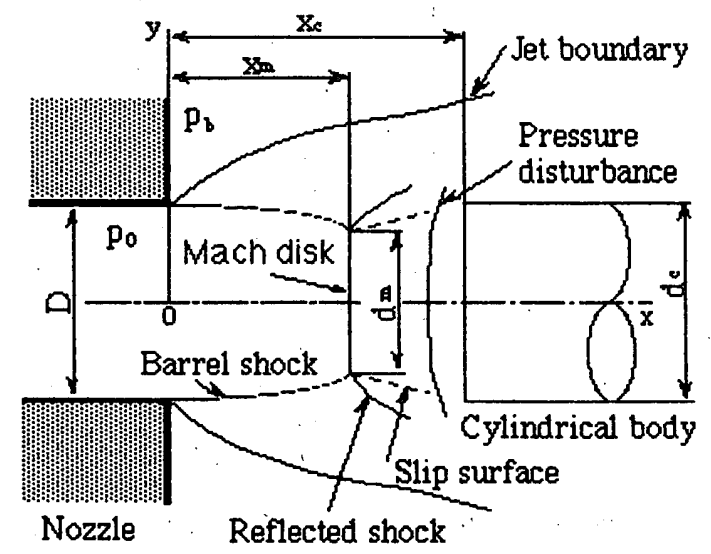

Fig. 2 Flow model and symbols 
Fig. 4 は, 自励振動時の压力比 $\phi$ と周波数解析により得 られた周波数ピーク $\mathrm{f}_{\max }$ との関倸を示している。図より， $\mathrm{f}_{\max }$

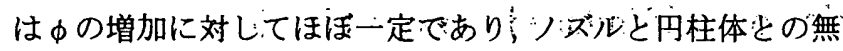
次元位置が長くなると，周波数ピーク $\mathrm{f}_{\max }$ は低くなる傾向を 示している.

Fig. 5 (a) は; "貯気圧 $\mathrm{p}_{0}$ で無次元化された自励振動時の 円柱体表面の時間平均圧力 $\mathrm{p}_{\mathrm{i}} / \mathrm{p} \mathrm{p}_{0}$ と，厓力比 $\phi$ との関保を示し ている. 図より， $\mathrm{p}_{\mathrm{a}} / \mathrm{p}_{0}$ は無次元位置 $\mathrm{xc} / \mathrm{D}$ による影響は少 なく，фの增加に対して堿少する傾向にあることがわかる。 また，無次元化された背圧 $\mathrm{p}_{\mathrm{b}} / \mathrm{p}_{0}$ と $\mathrm{p}_{\mathrm{m}} / \mathrm{p}_{0}$ との比較では，圧 力比が小さい領域では $\mathrm{p}_{\mathrm{b}} / \mathrm{p}_{0}$ の方が高く；圧力比が大きい領 域では $\mathrm{p}_{\mathrm{a}} / \mathrm{p}_{0}$ の方が高くなることがわかる.

Fig. 5 （b）は， $\mathrm{p}_{\mathrm{m}}$ を背圧 $\mathrm{p}_{\mathrm{b}}$ で無次元化したものである.

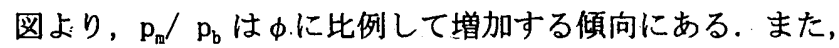
無次元位置 $\mathrm{x}_{\mathrm{c}} / \mathrm{D}$ による影響はなく，ほぼ同一になることを 示している: これらのことから; 時間平均圧力は円柱体の位 㯰による変化は少なく，圧力比に対して変化するといえる：

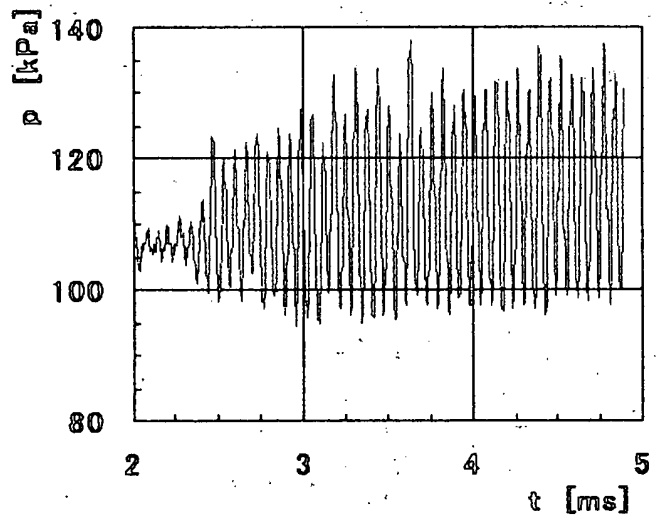

Fig. 3 Typical pressure history during self-indusced flow oscillation

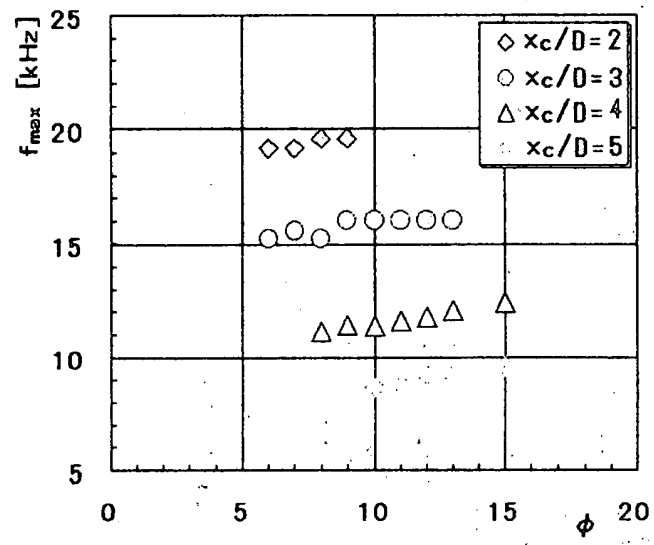

Fig. 4 Relation between peak frequency: and pressure ratio

\section{4 結果}

本研究では，円柱体に衝突する超音速噴流の自励振動に及 ぼす圧为比と位㯰の影響について, “実験的に考察を行った。 その結果を以下に要約する。

(1) 自励振動時の周波数ピーク 値 $\mathrm{f}_{\max }$ は, 圧力比 $\phi$ の増加 に対しでとんど変化せず, 円柱体の無次元位置 $\mathrm{x}_{\mathrm{c}} / \mathrm{D}$ に対して； $\mathrm{f}_{\max }$ は反比例する。

(2) 自励振動時の無次元時間平均圧力は，ノズルと円柱体 との無次元位置 $\mathrm{x}_{\mathrm{c}} / \mathrm{D}$ によらずほぼ一定で，圧力比に 対して変化する.

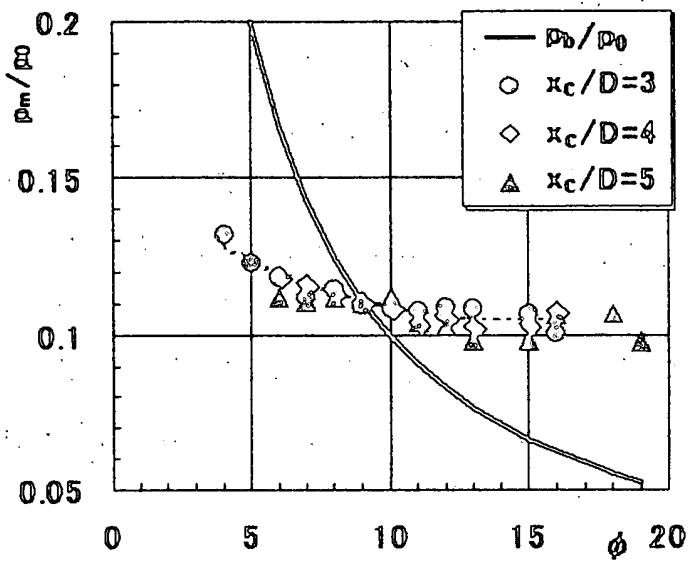

(a) $\mathrm{p}_{\mathrm{m}} / \mathrm{p}_{0}$

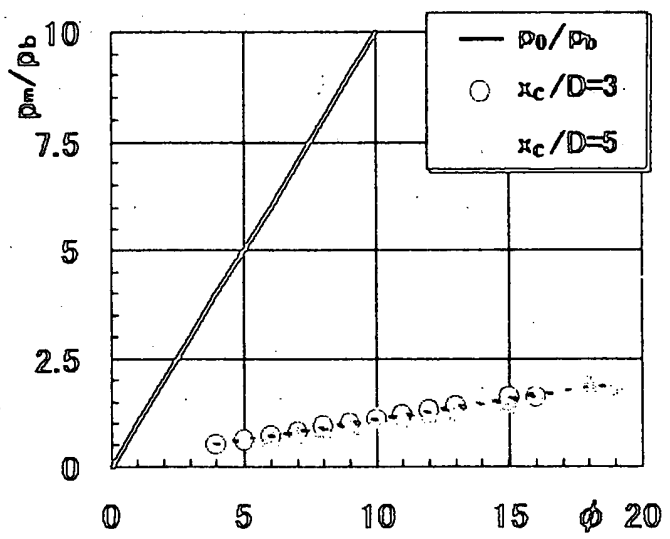

(b) $\mathrm{p}_{\mathrm{n}} / \mathrm{p}_{\mathrm{b}}$

Fig. 5 Relation between time average pressure on surface and pressure ratio

\section{参考文献}

(1) Jungowski, W. M., Aerospace Sci. (1978), Vol .18, p151-175.

(2) Kashimura, H. and Yasunobu, T., J. of Thermal Science., Vol.7, Nol(1998), p51-55. 